CZASOPISMO INŻYNIERII LA¿OWEJ, ŚRODOWISKA I ARCHITEKTURY JOURNAL OF CIVIL ENGINEERING, ENVIRONMENT AND ARCHITECTURE

JCEEA, t. XXXIV, z. 64 (2/II/17), kwiecień-czerwiec 2017, s. 255-266, DOI: 10.7862/rb.2017.97

\author{
Henryk WACHTA ${ }^{1}$ \\ Krzysztof BARAN ${ }^{2}$ \\ Marcin LEŚKO ${ }^{3}$
}

\title{
MOŻLIWOŚCI WYKORZYSTANIA W PRACACH REWITALIZACYJNYCH ZAAWANSOWANYCH APLIKACJI GRAFICZNYCH
}

\begin{abstract}
W klasycznym rozumieniu rewitalizacja obejmuje szereg działań zmierzających do przekształcenia na korzyść wyodrębnionego obszaru, który z różnych względów uległ degradacji. Kierunki tych przekształceń bywają różne, jednak w dużej mierze dotyczą obszarów historycznych, zniszczonych w czasie II Wojny Światowej. Współcześnie, na etapie planowania prac rewitalizacyjnych zabudowy historycznej, korzysta się z szeregu inżynierskich aplikacji graficznych, pozwalających wizualizować rozpatrywane koncepcje rewitalizacyjne. Dynamiczny postęp w rozwoju oprogramowania narzędziowego oraz możliwości obliczeniowych sprzętu komputerowego tworzy nową jakość w możliwościach wizualizacji obiektów architektonicznych. Celem podjętych i prezentowanych w artykule prac było ukazanie możliwości wykorzystania współczesnych, zaawansowanych aplikacji graficznych w pracach rewitalizacyjnych historycznej zabudowy Przemyśla. Do prac szczegółowych wytypowano wstępnie dwa obiekty istniejące niegdyś w śródmieściu: kamienicę nr 4, usytuowaną przy Placu na Bramie oraz Pasaż Gansa położony przy ulicy Mickiewicza. Na bazie istniejącej dokumentacji fotograficznej - najczęściej pocztówek, odtworzono formę przestrzenną elewacji tych obiektów wraz z bogatym wystrojem architektonicznym. Korzystając z szerokich możliwości modelowania cech powierzchni pokrywających elewacje oraz pokrycia dachowe, odwzorowano z dużym przybliżeniem stan materiałów ścian zewnętrznych i dachów rozpatrywanych obiektów. Wreszcie na etapie modelowania światła dziennego rozpatrzono dwa przypadki oświetlenia naturalnego: oświetlenie kierunkowe, występujące w porze bezchmurnej oraz rozproszone, występujące podczas jednorodnego zachmurzenia. Utworzone $\mathrm{w}$ toku pracy wizualizacje zostały naniesione na współczesne zdjęcia miejsc lokalizacji tych obiektów. Uzyskany efekt wizualny pozwala dokonać oceny trafności celu odtworzenia historycznych obiektów w otoczeniu współczesnej zabudowy oraz planować ich współczesną funkcję.
\end{abstract}

Słowa kluczowe: zabudowa historyczna, komputerowe odwzorowanie obiektów architektonicznych, narzędzia wizualizacyjne, modelowanie oświetlenia dziennego

${ }^{1}$ Autor do korespondencji / corresponding author: Henryk Wachta, Politechnika Rzeszowska, Katedra Energoelektroniki, Elektroenergetyki i Systemów Złożonych, ul. W. Pola 2, 35-959 Rzeszów; tel. 178651977; hwachta@prz.edu.pl

${ }^{2}$ Krzysztof Baran, Politechnika Rzeszowska, Katedra Energoelektroniki, Elektroenergetyki i Systemów Złożonych, ul. W. Pola 2, 35-959 Rzeszów; tel. 177432434; kbaran@ prz.edu.pl

${ }^{3}$ Marcin Leśko, Politechnika Rzeszowska, Katedra Energoelektroniki, Elektroenergetyki i Systemów Złożonych, ul. W. Pola 2, 35-959 Rzeszów; tel. 177432434; mlesko@prz.edu.pl 


\section{Wprowadzenie}

Według szacunków, w latach 1939-1945 w Przemyślu w wyniku działań wojennych zniszczeniu lub poważnemu uszkodzeniu uległo ok $50 \%$ zabudowy. Niektóre dzielnice, jak np. Dzielnica Żydowska, została zniszczona w 100\% [1]. Poziom zniszczeń sytuuje Przemyśl obok Warszawy wśród najbardziej zniszczony miast Polski. Z opracowań badaczy wynika, że w 1932 roku 30,1\% budynków w Przemyślu należało do Żydów, a 69,4\% do chrześcijan. Jednak w śródmieściu te proporcje przedstawiały się odwrotnie: $68,4 \%$ budynków należała do obywateli wyznania mojżeszowego, zaś $31,2 \%$ do obywateli wyznania rzymskokatolickiego. Oczywistym jest też, że przedstawiały one większą wartość historyczną i architektoniczną niż inne, położone w dzielnicach peryferyjnych [2]. Po wojnie miejscom tym przypisywano funkcje lokalnych parkingów, skwerów itp. Współcześnie $\mathrm{w}$ ramach uruchamianych szeroko prac rewitalizacyjnych można podjąć dyskusję nad ewentualnością odtworzenia tych obiektów. W ramach zespołu autorskiego podjęto próbę zaprezentowania użyteczności narzędzi informatycznych w komputerowym odtworzeniu dwu wybranych, historycznych obiektów śródmieścia Przemyśla [3]. Walor użyteczności przedstawiono na poziomie zdolności odwzorowania siatki przestrzennej obiektu, wizualizowania cech materiałów pokrywających elewacje obiektów rzeczywistych oraz oddziaływania oświetlenia dziennego na obiekt oraz jego bezpośrednie otoczenie. Do prac szczegółowych wybrano kamienicę Rosiewicza nr 4 oraz Pasaż Gansa. Oba obiekty zlokalizowane były przy ulicy Mickiewicza w Przemyślu.

\section{Komputerowe odwzorowanie kamienicy Rosiewicza nr 4, usytuowanej przy Placu na Bramie w Przemyślu}

Kamienica usytuowana była w ciągu zabudowy, przy wylocie ulicy Mickiewicza w stronę Placu na Bramie (rys. 1). Był to dwupiętrowy, bardzo atrakcyjny architektonicznie obiekt z poddaszem i czterema bogato zdobionymi balkonami. Fasadę oraz motywy dekoracyjne umieszczone na konsolach oraz na płycinach cechowała symetria [9]. Kamienica została zniszczona 8 września 1939 r. w wyniku nalotów lotnictwa niemieckiego. Poziom zniszczeń był tak duży, iż nie zdecydowano się na jej odbudowę, i poddano całkowitej rozbiórce (rys. 2). Współcześnie miejsce to jest niezabudowane, tworząc mało estetyczną lukę w ciągu historycznych kamienic. 


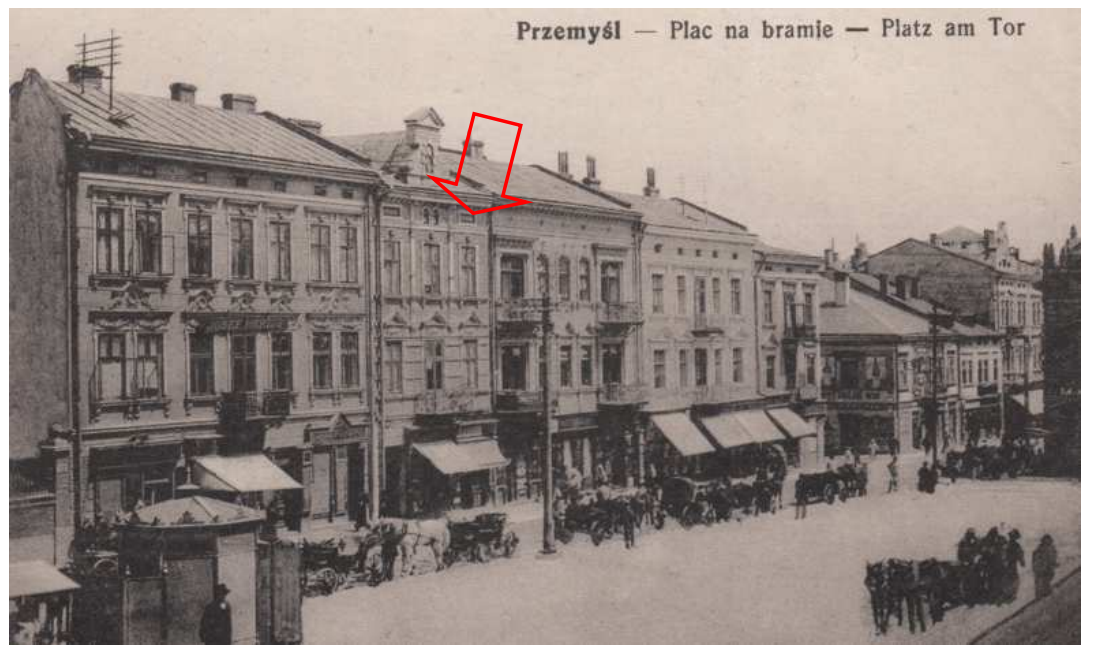

Rys. 1. Historyczna pocztówka z widokiem na dawny Plac Fiakrów (obecnie Plac na Bramie), strzałka oznacza kamienicę Rosiewicza [4]

Fig. 1. Historical postcard with the view of the former Fiacre Square (now the Square at the Gate), the arrow indicates the Rosiewicz tenement house [4]

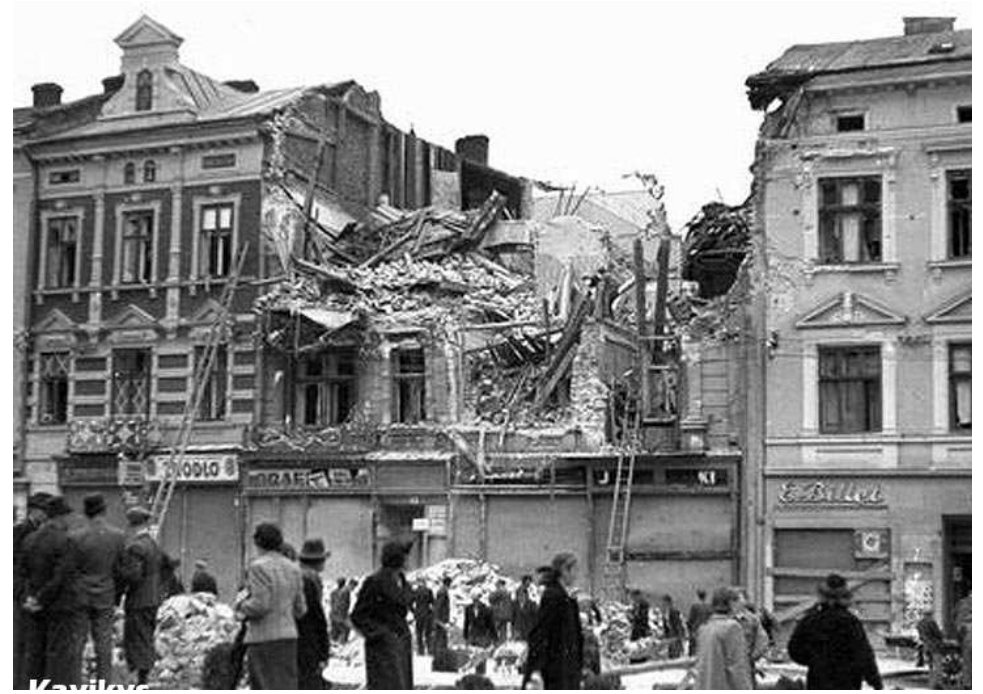

Rys. 2. Widok zbombardowanej 8 września 1939 r. przez lotnictwo niemieckie kamienicy Rosiewicza [5]

Fig. 2. View of the Rosiewicz tenement house bombed on September 8 by the German air force [5]

Szczególnie duże nasycenie elementów wystroju elewacji oraz balustrad balkonów było powodem, iż zdecydowano się na komputerowe odwzorowanie geometrii tej kamienicy. Wykonane zostały żmudne poszukiwania dostępnej 
dokumentacji fotograficznej obiektu oraz analiza cech geometrycznych poszczególnych stref fasady. Ostatecznie całkowita złożoność geometryczna modelu zamknęła się liczbą ponad 1500000 poligonów oraz podobną liczbą wierzchołków. Miarą możliwości skutecznego modelowania komputerowego tego typu obiektów jest przykład wykonanego pojedynczego ornamentu, który przekształcano korzystając z dostępnych funkcji aplikacji graficznej (rys. 3) [10,11].
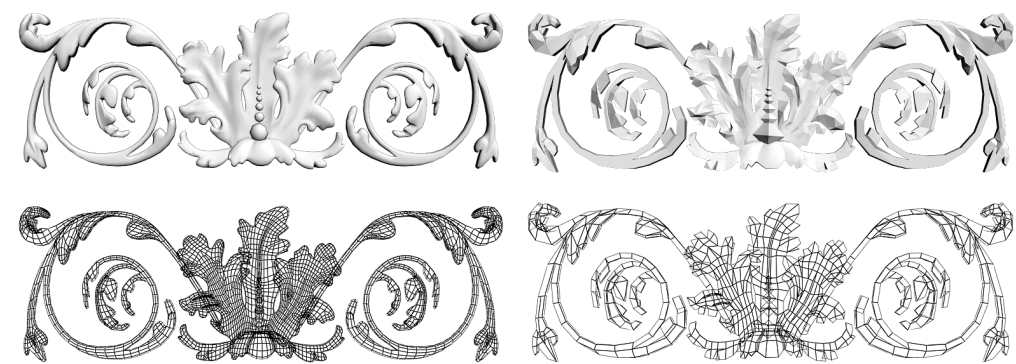

Rys. 3. Element wystroju elewacji z zagęszczoną siatką po lewej, oraz ten sam obiekt z wyłączoną opcją zagęszczenia po prawej. Na górze widok cieniowany, na dole widok krawędziowy [6]

Fig. 3. Element of the façade interior with the dense grid on the left, and the same object with the disabled option of density on the right. The shaded view on the top, the edge view on the bottom [6]

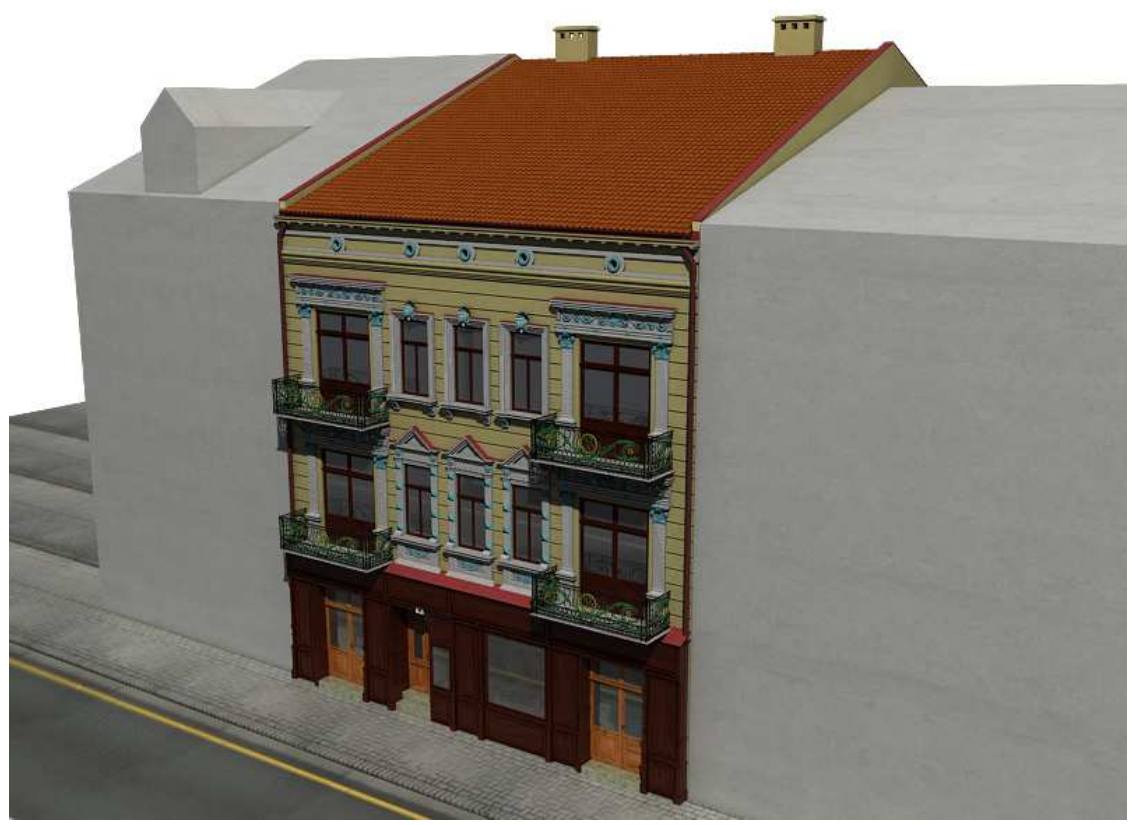

Rys. 4. Wizualizacja kompletnego modelu komputerowego kamienicy Rosiewicza [6]

Fig. 4. Visualisation of the complete computer model of the Rosiewicz tenement house [6] 
O ile odwzorowanie geometrii kamienicy było możliwe na podstawie dobrej jakości pocztówek z okresu międzywojennego, o tyle brak było precyzyjnych informacji o kolorystyce elewacji. Dlatego też, przeanalizowano podobną zabudowę w śródmieściu Przemyśla. Na tej podstawie zdefiniowano kolorystykę poszczególnych materiałów pokrywających elewację obiektu.

Dla uzyskania realistycznych efektów oddziaływania czasu na materiały elewacji (zacieki, zabrudzenia dolnej partii ściany itp.) wykorzystano procedury modelowania tekstur dostępne w aplikacji graficznej $[12,13]$. Finalnie uzyskano wizualizację komputerową obrazującą obiekt rzeczywisty (rys. 4).

Zasadniczo taka postać wizualizacji jest wystarczająca i może służyć do analiz rewitalizacyjnych, jednak znacznie atrakcyjniejsze jest wkomponowanie wizualizacji komputerowej we współczesne zdjęcie otoczenia. W tym przypadku założono jeden z możliwych sposobów oddziaływania oświetlenia naturalnego oświetlenie bezchmurne. Dla pory dnia, odpowiadającej kierunkowości padania cieni na zdjęciu współczesnym, przygotowano w środowisku komputerowym analogiczny model rozkładu cieni modułu oświetleniowego [14]. Dzięki temu możliwe było późniejsze połączenie ze sobą obrazu rzeczywistego otoczenia kamienicy ze stworzonym komputerowo obrazem obiektu (rys. 5). Oczywiście drugim warunkiem było takie ustawienie umownego obserwatora obiektu w środowisku aplikacji graficznej, aby odpowiadało ono miejscu obserwacji w środowisku rzeczywistym.

Rys. 5. Render cieni powstałych na elementach elewacji na etapie modelowania oświetlenia [6]

Fig. 5. Render of shadows created on the façade elements on the light modelling stage [6]

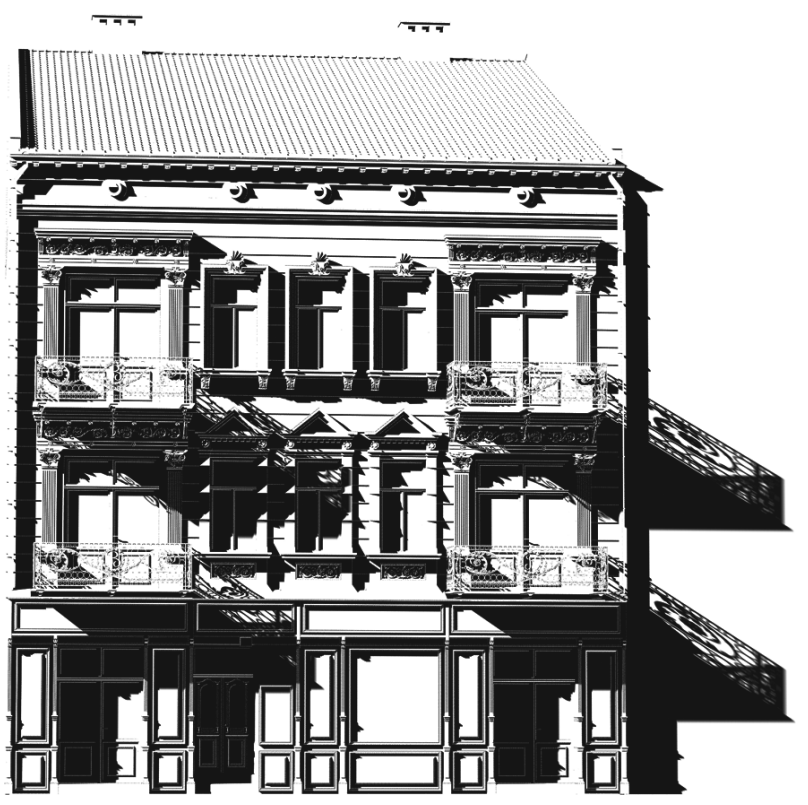




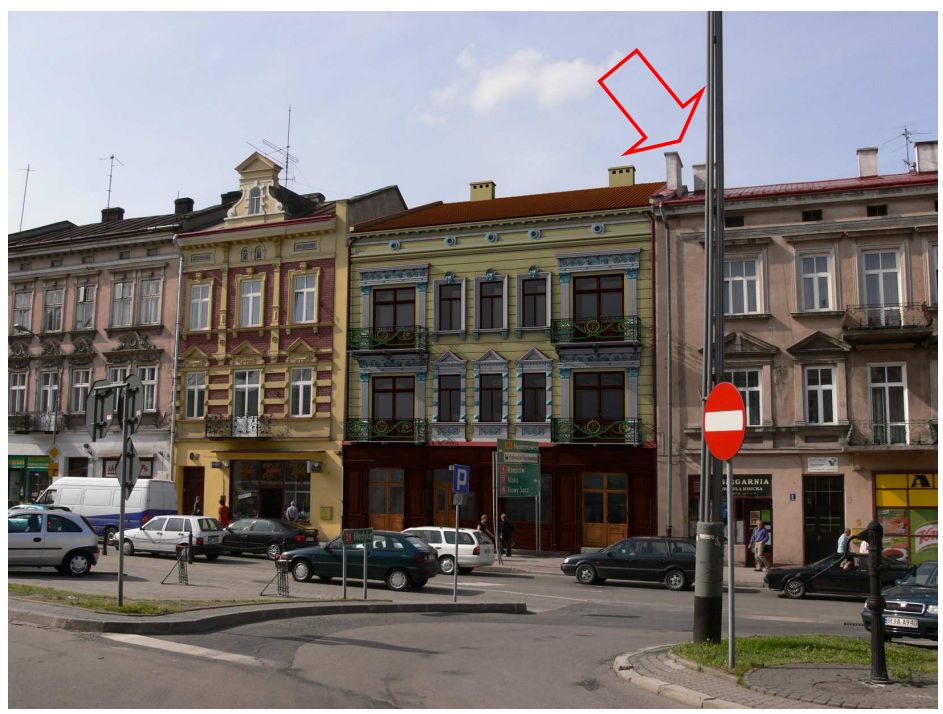

Rys. 6. Widok na współczesny ciąg zabudowy z naniesionym modelem komputerowym kamienicy [6]

Fig. 6. View of the string of buildings with the fitted computer model of the building [6]

Rezultat połączenia tych dwu obrazów ilustruje rys. 6. Istotnie udało się uzyskać na istniejącym współcześnie fragmencie elewacji (kamienica najbardziej wysunięta na prawo) cienie balkonów kamienicy współcześnie nieistniejącej. W odczuciu autorów powstała kompozycja może stanowić dobry materiał wyjściowy do prób odtworzenia kamienicy z nowoczesną funkcją jej wnętrza.

\section{Komputerowe odwzorowanie Pasażu Gansa w Przemyślu}

Pasażem Gansa nazywano przed II wojną światową okazały gmach stojący niegdyś na Placu Legionów w Przemyślu. Obecnie w bardzo ubogiej literaturze na jego temat zwykle spotyka się określenie Hotel Royal, które pochodzi od nazwy luksusowego hotelu mieszczącego się na 1 i 2 piętrze tego budynku, pasażem Gansa, zaś rejon jego umiejscowienia. Gmach Pasażu został wybudowany przed rokiem 1895 przez jedną z firm lwowskich. Jego właścicielem od początku był Israel Gans. Mieściły się tam oprócz hotelu księgarnia M.G. Rosenfelda, restauracja i piwiarnia, mleczarnia i herbaciano-kawiarnia [15] (rys. 7). Został poważnie uszkodzony podczas niemieckiego bombardowania 8 września 1939 roku. Podobnie jak kamienica Rosiewicza został po wojnie całkowicie rozebrany. Na jego miejscu zorganizowano parking samochodowy (rys. 8). 


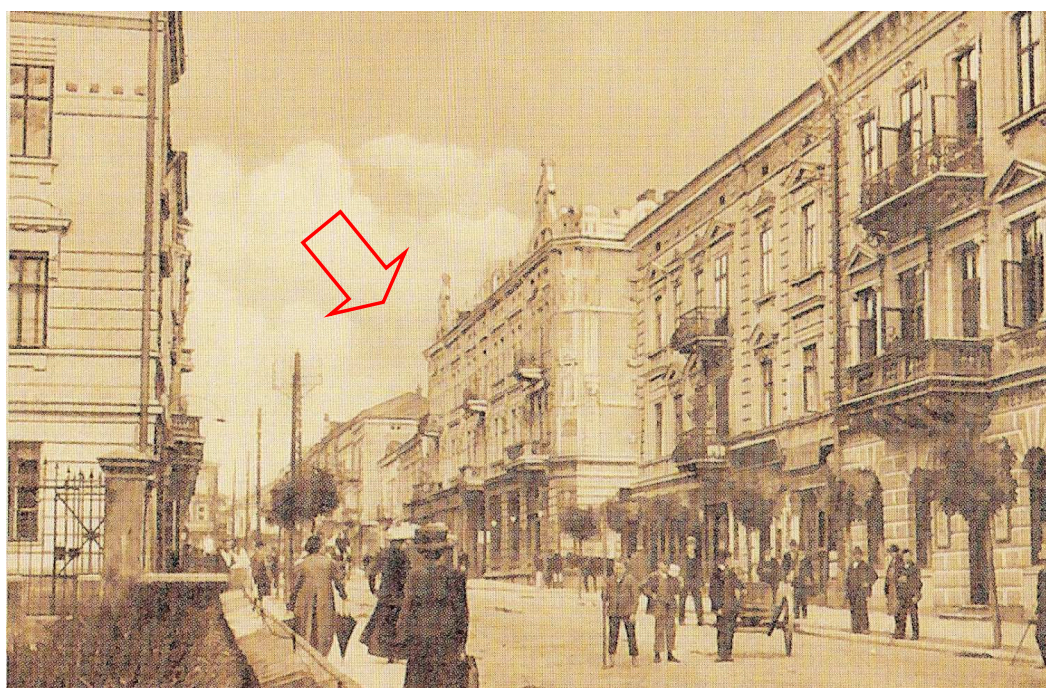

Rys. 7. Widok Pasażu Gansa na historycznej widokówce z pocz. XX w. [7]

Fig. 7. View of the Gans Passage on the historical postcard from the beginning of the XX c. [7]

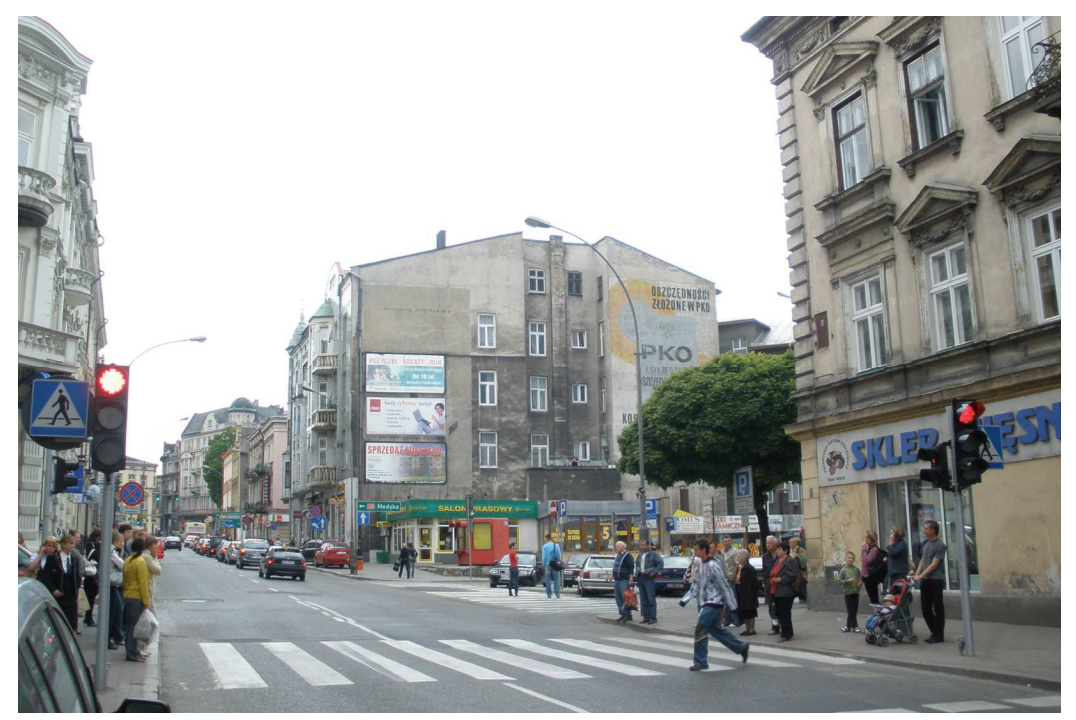

Rys. 8. Współczesny widok miejsca lokalizacji Pasażu Gansa [8]

Fig. 8. Contemporary view of the location of the Gans Passage [8]

W odróżnieniu do wcześniejszego obiektu Pasaż Gansa obejmował nie jedną ale trzy elewacje. W efekcie cały model geometryczny zawierał około 3150000 poligonów oraz około 2900000 wierzchołków (rys. 9). Zgodność wymiarów 
modelu krawędziowego Pasażu z obiektem rzeczywistym ustalono analizując dostępne zdjęcia i widokówki obiektu i uwzględniając perspektywiczne zniekształcenia wymiarowe. Weryfikacja przyjętych wymiarów modelu została przeprowadzona w oparciu o dokumentację satelitarną miejsca lokalizacji obiektu oraz pomiary porównawcze charakterystycznych elementów architektonicznych obiektów współcześnie istniejących i sąsiadujących z obiektem.

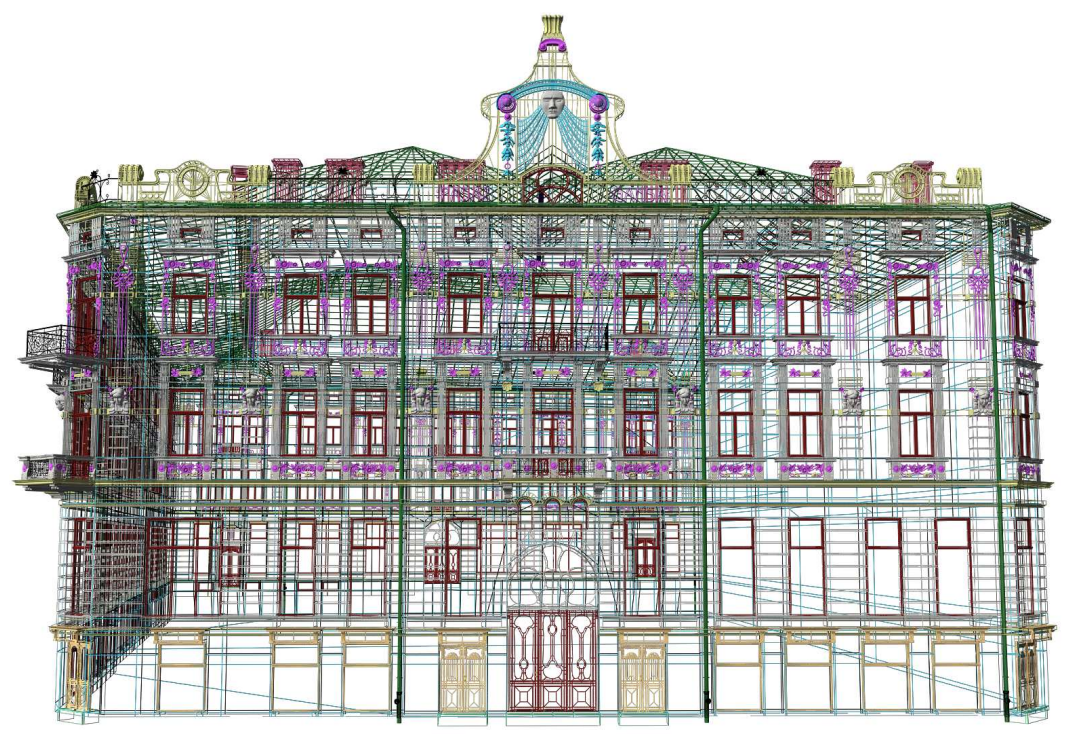

Rys. 9. Model krawędziowy Pasażu Gansa [6]

Fig. 9. Edge model of the Gans Passage [6]

Budynek został zaprojektowany w stylu secesyjnym. Z tego właśnie względu elewacje pokryte były dużą liczbą dekoracyjnych motywów roślinnych np. płyciny umiejscowione pod parapetami, gdzie umieszczono motyw kwiatów słonecznika. Bez wątpienia tak duży stopień komplikacji geometrycznej zdobień elewacji był pewnego rodzaju próbą możliwości oprogramowania graficznego. Jak widać na rysunku nr 9 zadanie zostało wykonane. Można jedynie dodać, iż niektóre elementy dekoracyjne elewacji zostały odwzorowane w środowisku graficznym z dokładnością mniejszą niż $5 \mathrm{~cm}$.

Sporym wyzwaniem okazało się przygotowanie charakterystyki kolorystycznej elewacji Pasażu Gansa. Niestety dostępna dokumentacja fotograficzna obiektu jest praktycznie czarno-biała. Pomocna w przyporządkowaniu dużej liczbie zdobień elewacji właściwej kolorystyki okazała się analiza obiektów stylu secesyjnego istniejących współcześnie. Finalnie powstał pełny model Pasażu Gansa, Jego wizualizację przedstawiono na rys. 10. 

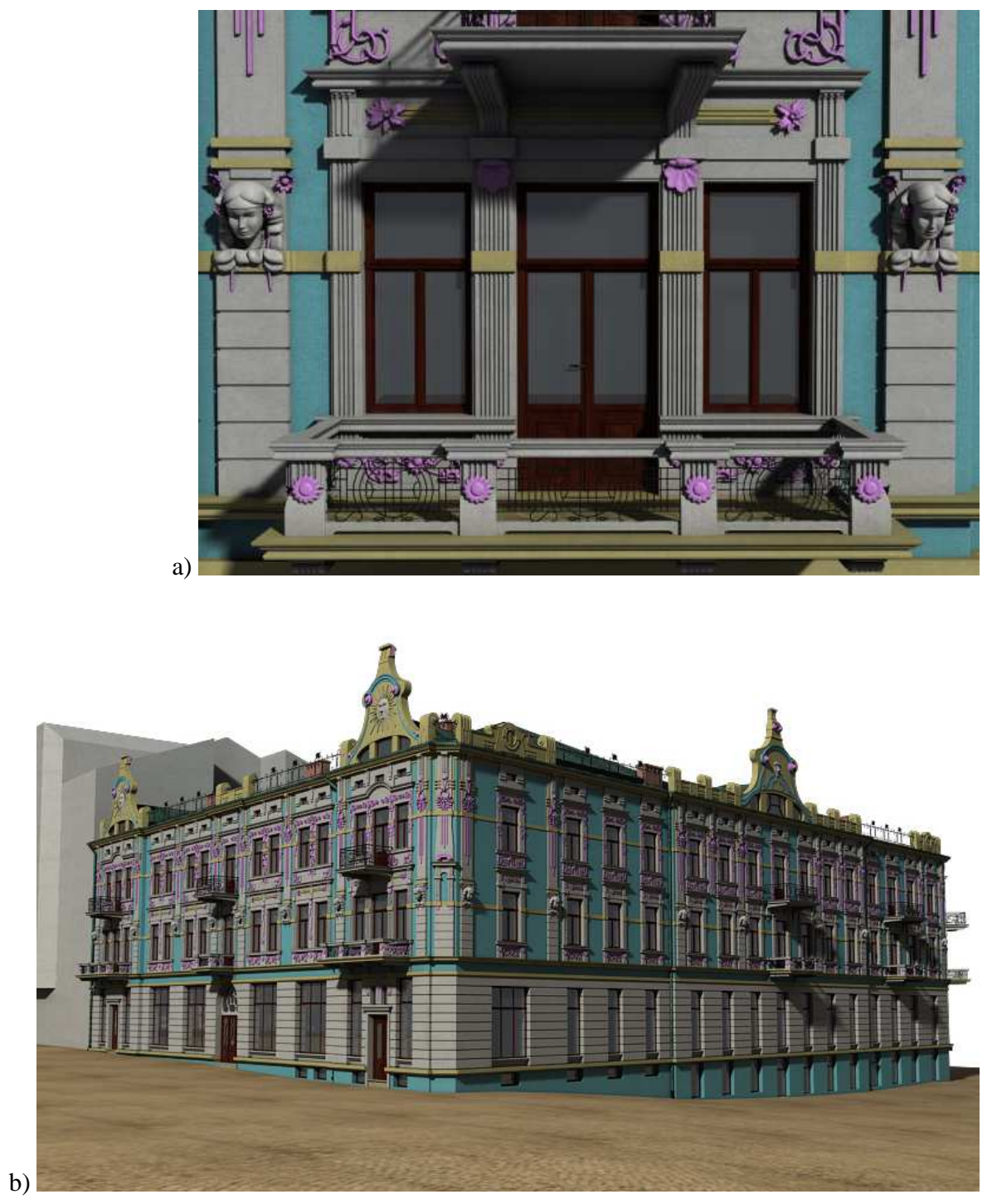

Rys. 10. Widok kompletnego modelu Pasażu Gansa, a - fragment elewacji z roślinną ornamentyką, b - pełny widok dwu elewacji obiektu [6]

Fig. 10. View of the complete model of the Gans Passage, a - detail of the facade with the plant ornamentation, $\mathrm{b}$ - full view of two building facades [6] 


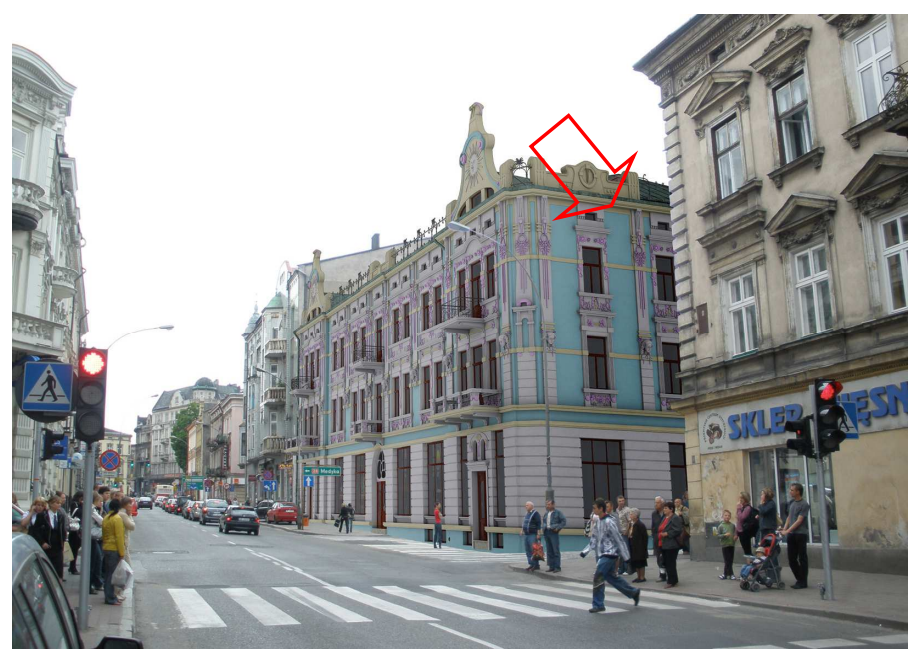

Rys. 11. Wizualizacja połączenia współczesnego otoczenia z modelem Pasażu Gansa [6]

Fig. 11. Visualisation of the combination of the modern surroundings with the model of the Gans Passage [6]

Ostatnim elementem prezentacji możliwości wizualizacyjnych aplikacji graficznych było naniesienie na współczesne zdjęcie komputerowej wizualizacji Pasażu Gansa. W tym przypadku wybrano drugą metodę oświetlenia modelu metodę światła rozproszonego, właściwego dla oświetlenia naturalnego w warunkach zachmurzenia. Wówczas przy wielokierunkowym oświetleniu nie obserwuje się cieni $[16,17]$. Rysunek 11 przedstawia ostateczny rezultat prac. Bez wątpienia prezentowane ujęcie jest bardziej korzystne niż współczesny widok tego miejsca.

\section{Podsumowanie}

Przedstawione dwa przykłady próby komputerowego odtworzenia historycznej zabudowy Przemyśla dają obraz wizualizacyjnych możliwości aplikacji graficznych. Zarówno na poziomie aplikacyjnym jako i obliczeniowym istnieją duże możliwości odwzorowywania skomplikowanych form zabudowy historycznej.

Wkomponowana w istniejącą zabudowę wizualizacja Kamienicy Rosiewicza wskazuje na słuszność podejmowania starań rewitalizacji tego i podobnych miejsc w Przemyślu. Poza uporządkowaniem linii zabudowy została wprowadzona harmonia stylu tej tak zwanej ,plomby” budowlanej. Bez trudu można wskazać przykłady nieudanych realizacji podobnych ,plomb”.

Gmach Hotelu Royal jest przykładem pięknej secesji roślinnej, którą z rozmachem stosowano jeśli chodzi o dekoracje i ostrożnie jeśli chodzi o bryłę obiektu. Asymetrię stosowano z umiarem stosując ją raczej do wykończenia 
elewacji niż do planu budynku. Zarówno w Polsce jak i na świecie budynki wybudowane w tym stylu należą do rzadkości. Jest to spowodowane krótką historią stylu Art. Nouveau, liczącą zaledwie nieco ponad 20 lat. Dlatego też obiekt ten jest tym bardziej cenny.

W propozycjach rewitalizacyjnych można ująć odtworzenie elewacji Pasażu Gansa i nadanie temu obiektowi nowej funkcji. Zaznaczając, iż jest on zlokalizowanych blisko głównego dworca kolejowego można rozważyć stworzenia wewnątrz galerii wielkopowierzchniowej lub nawet wielopoziomowego parkingu samochodowego.

\section{Literatura}

[1] http://wojnawp.republika.pl/zniszcz/z.html \{dostęp 12.06.2016 r.\}.

[2] Stępień S.: Studia Przemyskie tom 2, Przemyśl 2004.

[3] Murdock Kelly L.: 3ds Max 8 Biblia, Helion, Gliwice 2007.

[4] http://www.swistak.pl/a58476502,A-02-PRZEMYSL-PLAC-NABRAMIE.html\#zdjecia \{dostęp 12.06.2016 r.\}.

[5] http://przemysl.fotopolska.eu/nieistniejace,248,20/woj.podkarpackie.html \{dostęp 12.06.2016 r.\}.

[6] Wizualizacje komputerowe powstałe w ramach działalności Koła Naukowego Elektronergetyk.

[7] http://viewcardsworld.blogspot.com/2012_04_01_archive.html \{dostęp 12.06.2016 r.\}.

[8] Dokumentacja fotograficzna autorów.

[9] Cole E.: Architektura Style i detale, Arkady, Warszawa 2008.

[10] Ross A., Bousquet M.: 3ds max 5 Projekty i rozwiązania, Helion, Gliwice 2004.

[11] Murdock K.L.: 3ds max 4 Techniki modelowania, Helion, Gliwice 2002.

[12] Bell J.A.: 3D Studio MAX 3 efekty specjalne, Helion, Gliwice 2000.

[13] Adobe: Adobe Photoshop CS2 Podręcznik użytkownika, Adobe Systems Incorporated, 2005.

[14] Birn J.: Cyfrowe oświetlenie i rendering, Helion, Gliwice 2007.

[15] Wójcik A.: Spacerkiem po Przemyślu w roku 1900, Rzeszowskie Zakłady Graficzne S.A. Przemyśl 2003.

[16] Busch D.D.: Fotografia cyfrowa i obróbka obrazu, Helion, Gliwice 2002.

[17] Bucher Ch.: Oświetlenie Warsztaty fotograficzne, Helion, Gliwice 2009.

Praca została wykonana $w$ ramach działalności Koła Naukowego Elektroenergetyk, z wykorzystaniem aparatury zakupionej $w$ wyniku realizacji Projektu: "Budowa, rozbudowa i modernizacja bazy naukowo-badawczej Politechniki Rzeszowskiej”, wspótfinansowanego ze środków Unii Europejskiej w ramach Regionalnego Projektu Operacyjnego Województwa Podkarpackiego na lata 2007-2013, Oś priorytetowa 1 - Konkurencyjna i innowacyjna gospodarka. 


\section{POSSIBILITIES OF USING THE ADVANCED GRAPHIC APPLICATIONS IN THE REVITALISATION WORKS}

\section{S u m m a r y}

In the classic sense, revitalisation includes a number of actions aimed to transform the isolated area for the benefit, which for various reasons has been degraded. The directions of these transformations can be different, however, they largely concern the historical areas, damaged during World War II. Today, at the planning stage of the revitalisation works of the historic buildings, we use a series of engineering graphic applications, which allow to visualise the considered revitalisation concepts. The dynamic progress in the development of the tool software and computing capabilities creates a new quality in the capabilities to visualise the architectural objects. The aim of the undertaken and presented works in the article was to show the possibilities for using the modern, advanced graphic applications in the revitalisation works of the historic buildings of Przemyśl. For the detailed works two buildings have been initially selected, which have once existed in the downtown: tenement house no. 4, located by the Square on the Gate and the Gans Passage located at Mickiewicz Street. On the basis of the existing photographic documentation - usually postcards, the spatial form of these elevations was restored, with the rich architectural interior. Using the extensive possibilities for modelling the features of the surfaces covering the facades and the roofing, the condition of the materials of the exterior walls and the roofs of the considered objects was closely mapped. Finally, at the stage of modelling the daylight, two cases of natural lighting were considered: directional light, occurring in the cloudless time, and distributed, occurring during a uniform cloud cover. Visualisation created in the workflow have been applied to the contemporary photos of the locations of these buildings. The obtained visual effect allows to make the assessment of the relevance of the aim to restore the historical buildings surrounded by the modern buildings and to plan their contemporary function.

Keywords: historical buildings, computer mapping of architectural buildings, visualisation tools, daylight modelling

Przestano do redakcji: $19.06 .2016 r$.

Przyjęto do druku: 30.06 .2017 r. 